\title{
Release and extracellular metabolism of ATP by ecto-nucleotidase eNTPDase 1-3 in hypothalamic and pituitary cells
}

\author{
Mu-Lan He, Arturo E. Gonzalez-Iglesias, Melanija Tomic \& Stanko S. Stojilkovic \\ Section on Cellular Signaling, Endocrinology and Reproduction Research Branch, National Institute of Child Health and \\ Human Development, National Institutes of Health, Bethesda, Maryland, USA
}

Received 23 August 2004; accepted in revised form 22 October 2004

Key words: $\alpha \mathrm{T} 3-1$ cells, apyrase, ARL67156, $\mathrm{GH}_{3}$ cells, GT1-7 cells, P2X receptors

\begin{abstract}
Hypothalamic and pituitary cells express G protein-coupled adenosine and P2Y receptors and cation-conducting P2X receptor-channels, suggesting that extracellular ATP and other nucleotides may function as autocrine and/or paracrine signaling factors in these cells. Consistent with this hypothesis, we show that cultured normal and immortalized pituitary and hypothalamic cells release ATP under resting conditions. RT-PCR analysis also revealed the presence of transcripts for ecto-nucleotidase eNTPDase 1-3 in these cells. These enzymes were functional as documented by degradation of endogenously released and exogenously added ATP. Blocking the activity of eNTPDases by ARL67156 led to an increase in ATP release in perifused pituitary cells and inhibition of degradation of extracellularly added ATP. Furthermore, the addition of apyrase, a soluble ecto-nucleotidase, and the expression of recombinant mouse eNTPDase-2, enhanced degradation of both endogenously released and exogenously added ATP. The released ATP by resting hypothalamic cells was sufficient to activate and desensitize high-affinity recombinant $\mathrm{P} 2 \mathrm{X}$ receptors, whereas facilitation of ATP metabolism by the addition of apyrase protected their desensitization. These results indicate that colocalization of ATP release sites and ecto-nucleotidase activity at the plasma membrane of hypothalamic and pituitary cells provides an effective mechanism for the operation of nucleotides as extracellular signaling molecules.
\end{abstract}

Abbreviations: $\left[\mathrm{Ca}^{2+}\right]_{\mathrm{i}}$ - intracellular calcium concentration; eNTPDase-ecto-nucleoside triphosphate diphosphohydrolase; P1Rs - adenosine G protein-coupled receptors; P2XRs - purinergic receptor channels; P2YRs - G protein-coupled purinergic receptors; PRL - prolactin

\section{Introduction}

ATP and UTP have to be released by cells to act as extracellular messengers and are then hydrolyzed by ectonucleotidases, resulting in the formation of the respective nucleoside and free phosphate. The products of this hydrolytic cascade, ADP, UDP and adenosine, also act as extracellular messengers by activating distinct plasma membrane receptors in numerous excitable and nonexcitable cells [1]. These receptors were termed purinergic and they belong to two groups: $\mathrm{P} 1$ receptors (P1Rs) that are activated by adenosine and $\mathrm{P} 2$ receptors (P2Rs) that recognize mainly ADP, ATP, UDP and UTP. Two families compose P2Rs: The ligand-gated channel family (P2XR) and the $G$ protein-coupled receptor family (P2YR) [2]. Initially, it was believed that single enzymes exist for the

Correspondence to: Dr Stanko S. Stojilkovic, ERRB/NICHD, Bldg. 49, Room 6A-36, 49 Convent Drive, Bethesda, MD 20892-4510, USA. Tel: +1-301-4961638; Fax: +1-301-5947031; E-mail: stankos@helix.nih.gov. hydrolysis of ATP (ecto-ATPase), ADP (ectoADPase) and AMP (ecto-5'-nucleotidase), and that these enzymes are expressed on the plasma membrane with their catalytic domain facing the extracellular space [3]. Currently identified ecto-nucleotidases include members of the ecto-nucleoside triphosphate diphosphohydrolase family of enzymes (eNTPDase) and several other subfamilies of enzymes. Three out of six known eNTPDases (termed eNTPDase-1, -2 , and -3 ) are expressed in plasma membrane and, like P2XRs, are composed of two transmembrane domains, which place most of the protein extracellularly and its Nand C-termini intracellularly. These enzymes not only hydrolyze extracellular ATP and/or ADP to AMP, but also metabolize other nucleotide tri- and diphosphates, including UTP and UDP [1].

Normal and immortalized anterior pituitary cells express $A_{1}, A_{2 A}$ and $A_{2 B}$ subtypes of $P 1$ receptors [4-6]. Several earlier published reports have also indicated the expression of P2Rs in anterior pituitary [7-14]. The first P2 receptor identified in this tissue was $\mathrm{P} 2 \mathrm{Y}_{2} \mathrm{R}$ [15]. Recently, we showed the presence of transcripts for four additional 
members of P2YRs: $\mathrm{P} 2 \mathrm{Y}_{1}, \mathrm{P}_{2} \mathrm{Y}_{4}, \mathrm{P}_{2} \mathrm{Y}_{6}$ and $\mathrm{P} 2 \mathrm{Y}_{12}$ in anterior pituitary cells and identified the $\mathrm{P} 2 \mathrm{Y}_{1} \mathrm{R}$ subtype in lactotroph fraction of cells [16]. Earlier studies revealed the expression of $\mathrm{P} 2 \mathrm{X}_{2 \mathrm{a}} \mathrm{R}$ and its spliced form $\mathrm{P} 2 \mathrm{X}_{2 \mathrm{~b}} \mathrm{R}$ in somatotrophs and gonadotrophs $[17,18]$, as well as $\mathrm{P} 2 \mathrm{X}_{3} \mathrm{R}$, $\mathrm{P} 2 \mathrm{X}_{4} \mathrm{R}$ and $\mathrm{P} 2 \mathrm{X}_{7} \mathrm{R}$ in other pituitary cell types $[17,19]$. In lactotrophs, the $\mathrm{P} 2 \mathrm{X}_{4} \mathrm{R}$ subtype provides a major pathway for calcium-influx-dependent signaling and prolactin (PRL) secretion [16]. Thus, of the 17 known nucleotide receptors, 12 are probably expressed in the secretory anterior pituitary. The non-secretory anterior pituitary cells as well as both neuronal and intermediate lobes of pituitary also express functional $\mathrm{P} 1 / \mathrm{P} 2$ receptors [9, 20-23]. In that respect, only the brain expresses more of these receptor subtypes, indicating the potential relevance of nucleotidedependent receptor signaling pathways in pituitary cell functions.

In contrast to the well-documented expression of P1Rs and P2Rs in pituitary cells, the knowledge about the release of purines and pyrimidines by pituitary cells is limited to two reports. Chen et al. [24] reported that calcium ionophore A23187 induced release of ATP from pituitary cells in a concentration- and calcium-dependent manner. Tomic et al. [14] observed a GnRH-induced increase in ATP release in perifused pituitary cells. To our knowledge, the expression and role of ecto-nucleotidases in controlling the extracellular messenger functions of nucleotides has not been previously established in pituitary cells. Here we studied the release of ATP in normal and immortalized pituitary cells as well as in GnRH-secreting GT1-7 neurons. In addition, we addressed the efficacy of the released ATP to activate receptors. We also characterized the capacity of these cells to metabolize the endogenously released and exogenously added ATP. The expression of transcripts for eNTPDase 1-3 was also analyzed, as well as the inhibition of ATP degradation by ARL67156, a blocker of these enzymes.

\section{Materials and methods}

\section{Cell cultures and treatments}

Experiments were performed in anterior pituitary cells from normal postpubertal female Sprague-Dawley rats obtained from Taconic Farm (Germantown, NY), immortalized mouse $\alpha$ T3-1 gonadotrophs, mouse AtT20 corticotrophs, rat $\mathrm{GH}_{3}$ lacto-somatotrophs, as well as in mouse GnRH-secreting hypothalamic GT1-7 cells. Pituitary cells were dispersed as described previously [25] and cultured as mixed cells in medium 199 containing Earle's salts (Invitrogen, Carlsbad, CA), sodium bicarbonate, 10\% heatinactivated horse serum (Invitrogen), penicillin $(100 \mathrm{U} / \mathrm{ml})$ and streptomycin $(100 \mu \mathrm{g} / \mathrm{ml})$. GT1-7 cells and $\alpha \mathrm{T} 3-1$ gonadotrophs were cultured in Dulbecco's modified Eagle's medium (DMEM)/Ham's F12 medium (1:1), containing $10 \%(\mathrm{v} / \mathrm{v})$ heat-inactivated fetal bovine serum, and $100 \mu \mathrm{g} / \mathrm{ml}$ gentamicin (Invitrogen). AtT-20 immortal- ized corticotrophs cells were cultured in DMEM medium supplied with $10 \%(\mathrm{v} / \mathrm{v})$ heat-inactivated fetal bovine serum, and $100 \mu \mathrm{g} / \mathrm{ml}$ gentamicin. $\mathrm{GH}_{3}$ immortalized pituitary cells (ATCC, Manassas, VA) were cultured in F12K Nutrient Mixture with Kaighn's modification supplemented with $1.5 \mathrm{~g} / 1$ sodium bicarbonate, $15 \%$ heat-inactivated horse serum, $2.5 \%$ fetal bovine serum, and $100 \mu \mathrm{g} / \mathrm{ml}$ gentamicin. Cells were treated with ATP (Sigma, St. Louis, MO), apyrase (grade I, Sigma) and ARL67156 (Tocris, Ellisville, MO).

\section{Measurements of ATP and PRL}

ATP content was monitored using cells in static cultures and column perifusion experiments. For static culture experiments, cells were seeded at different densities in poly-D-lysine-coated 6 -well plates and cultured at $37^{\circ} \mathrm{C}$ for $24 \mathrm{~h}$. Before assay, cells in each well were washed twice with $1 \mathrm{ml}$ of ATP-free Krebs-Ringer buffer $(120 \mathrm{mM}$ $\mathrm{NaCl}, 5 \mathrm{mM} \mathrm{KCl}, 1.26 \mathrm{mM} \mathrm{CaCl} 2,0.7 \mathrm{mM} \mathrm{MgSO}$, $10 \mathrm{mM}$ Glucose, and $15 \mathrm{mM}$ HEPES, pH 7.4). Then, cells were incubated in $1 \mathrm{ml}$ per well of fresh ATP-free or ATP containing buffer. At the indicated times, samples $(\sim 0.6 \mathrm{ml}$ of supernatant) were collected and ATP concentration measured immediately. For perifusion experiments, $5 \times$ $10^{6}$ cells were incubated with preswollen cytodex-1 beads in $60-\mathrm{mm}$ Petri dishes for $24 \mathrm{~h}$. The beads with and without cells were then transferred to $0.5-\mathrm{ml}$ chambers and perifused with Krebs-Ringer medium containing $0.1 \%$ BSA for $2.5 \mathrm{~h}$ at a flow rate of $0.8 \mathrm{ml} / \mathrm{min}$ and at $37{ }^{\circ} \mathrm{C}$. Fractions were collected in 1-min intervals and immediately assayed for ATP contents using an ATP bioluminescent assay kit (Sigma) in TD-20/20 Luminometer (Turner Designs, Sunnyvale, CA). Calibration curves were constructed from measurements of standard solutions, which were diluted in the same medium as the corresponding solutions of unknown ATP concentration. Detection limit of the assay was $0.2 \mathrm{nM}$. PRL content in culture samples was determined by radioimmunoassay. Primary antibody and standard for PRL assay were provided by the National Pituitary Agency and Dr AF Parlow (Harbor-UCLA Medical Center, Torrance, CA), ${ }^{125}$ I-PRL was purchased from Perkin-Elmer Life Sciences (Boston, MA) and secondary antibody from Sigma.

\section{Reverse transcriptase-PCR analysis of eNTPDase expression}

Total RNA from rat anterior pituitary and hypothalamic tissues and cultured cells was extracted using TRIzol reagent (Invitrogen). After DNase I digestion, $2 \mu \mathrm{g}$ of total RNA was reverse-transcribed into first-strand cDNA with oligo-dT primers and SuperScriptII reverse transcriptase (Invitrogen). The cDNAs were then amplified with different eNTPDase isoform-specific primer sets in the non-conserved region. The oligonucleotide sequences of primers used for PCR amplification, with GeneBank accession numbers given in parentheses, are listed as: mouse 
eNTPDase-1 (AF037366): sense (1,389-1,409 bp, 5'-CAAGATCAAAGACAGCAACGC-3'), antisense (1,583-1,604 bp, 5'-TCCTGCTATACTGCCTCTTTCC-3'); mouse eNTPDase-2 (AF042811): sense (1,217-1,235 bp, 5'-CTGCACTGTAGCCATGTTC- $\left.3^{\prime}\right)$, antisense $(1,533-1,554$ bp, 5'-GAAGAGAGATAGCCGGGAGTTG-3'); mouse eNTPDase-3 (NM-178676): sense (1,485-1,504 bp, 5'-GATCCATCTACCCATACAGC-3'), antisense (1,684-1,704 bp, 5'-TGTGTGGTGTCACTCTGGTGG-3'); rat eNTPDase-1 (U81285): sense (546-565 bp, 5'-GAGCTACCCCTTTGACTTCC-3'), antisense (669-690 bp, 5'-CTGTTTCTGGCTGTCTGAGATG-3'); rat eNTPDase-2 (Y11835): sense (334-355 bp, 5'-CATGCTAGCACACCACTCTACC-3'), antisense (519-539 bp, 5'-AAGTTCTCCAGCAGGTAGTTG-3'); rat eNTPDase-3 (AJ437217): sense (1,001-1,023 bp, 5'-GCCGGAACGAAGCAGAGAAGAAG-3'), antisense $\left(1,224-1,245 \mathrm{bp}, 5^{\prime}\right.$-GAAGTCAAACACAGAAGCCACC-3').

The amplification was conducted in a Robocycler Thermal Cycler (Stratagene, La Jolla, CA) in a 50- $\mu$ l reaction volume containing $1 \mu \mathrm{l}$ of the first-strand cDNA as template, 1 unit of Taq DNA polymerase (Invitrogen), $0.5 \mu \mathrm{M}$ concentration of each primer, $0.2 \mathrm{mM}$ dNTP, and $1 \times$ PCR buffer ( $2 \mathrm{mM} \mathrm{MgCl}_{2}, 50 \mathrm{mM} \mathrm{KCl}, 20 \mathrm{mM}$ Tris- $\mathrm{HCl}, \mathrm{pH} 8.4$ ). Amplification of DNA templates was initiated by a denaturation step at $94{ }^{\circ} \mathrm{C}$ for $180 \mathrm{~s}$, followed by 35 cycles of denaturing at $94{ }^{\circ} \mathrm{C}$ for $45 \mathrm{~s}$, annealing at $52-60{ }^{\circ} \mathrm{C}$ for $30 \mathrm{~s}$, and extension at $72{ }^{\circ} \mathrm{C}$ for $60 \mathrm{~s}$. The reaction was then terminated by a final extension step at $72{ }^{\circ} \mathrm{C}$ for $10 \mathrm{~min}$. After PCR, a $10-\mu l$ aliquot of PCR products was sizefractionated by electrophoresis in a 1.2\% agarose gel and visualized by ethidium bromide staining. To check the integrity of RNA preparation, RT-PCR of GAPDH was also conducted as an internal control using primers GAPDH sense (5'-GGCATCCTGGGCTACACTG-3') and GAPDH antisense (5'-TGAGGTCCACCACCCTGTT-3').

\section{DNA constructs and transfection}

The coding sequences of the rat $\mathrm{P} 2 \mathrm{X}_{2}$ and $\mathrm{P} 2 \mathrm{X}_{3}$ subunits were isolated by RT-PCR [26], and subcloned into biscistronic enhanced green fluorescent protein expression vector, pIRES2-EGFP (Clontech, Palo Alto, CA) at the restriction enzyme site of $X h o \mathrm{I} / P_{\text {st }} \mathrm{I}$ for $\mathrm{P} 2 \mathrm{X}_{2} \mathrm{R}$ and $X h o \mathrm{I} / E c o R \mathrm{I}$ for $\mathrm{P} 2 \mathrm{X}_{3}$. Chimeric $\mathrm{P}_{2} \mathrm{X}_{2 \mathrm{a}} / \mathrm{P}_{2} \mathrm{X}_{3}$ subunit contain extracellular domain from $\mathrm{Val}^{60}$ to $\mathrm{Phe}^{301}$ of $\mathrm{P} 2 \mathrm{X}_{3} \mathrm{R}$ instead of the native $\mathrm{Ile}^{66}-\mathrm{Tyr}^{310}$ sequence of $\mathrm{P} 2 \mathrm{X}_{2} \mathrm{R}$ and was constructed as reported previously [27]. Mouse eNTPDase-2 cDNA clone (MGC clone 5806) was purchased from Invitrogen and the full-length cDNA fragment was released by $X h o \mathrm{I} / E c o R \mathrm{I}$ digestion and then directionally subcloned into mammalian expression vector, pcDNA3.1/V5HisA (Invitrogen). Plasmid DNAs for transfection were prepared using a QIAGEN Plasmid Maxi Kit (Qiagen, Germany). Before the day of transfection, mouse GT1-7 cells or $\alpha$ T3-1 cells were plated on $35 \mathrm{~mm}$ culture dishes or poly-D-Lysine coated 6-well plates. For each dish of cells, transient transfection of expression constructs was performed using $1 \mu \mathrm{g}$ DNA and $7 \mu$ LipofectAMINE
2000 reagent (Invitrogen) in $3 \mathrm{ml}$ serum-free OPTI-MEM. After $6 \mathrm{~h}$ of incubation, transfection mixture was replaced with normal culture medium. Cells were subjected to experiments $24-48 \mathrm{~h}$ after transfection.

\section{Calcium measurements}

Transfected GT1 cells (100,000 per $35 \mathrm{~mm}$ coverslip) were preloaded with $1 \mu \mathrm{M}$ Fura-2 acetoxymethyl ester (Fura-2/ AM; Molecular Probe, Eugene, OR) for $60 \mathrm{~min}$ at room temperature in Krebs Ringer medium. After dye loading, cells were incubated in Krebs Ringer medium and kept in the dark for at least $30 \mathrm{~min}$ before single-cell intracellular calcium concentration $\left(\left[\mathrm{Ca}^{2+}\right]_{\mathrm{i}}\right)$ measurements. Coverslips with cells were mounted on the stage of an Axiovert 135 microscope (Carl Zeiss, Oberkochen, Germany) attached to the Attofluor Digital Fluorescence Microscopy System (Atto Instruments, Rockville, MD). Cells were stimulated with ATP and the dynamic changes of $\left[\mathrm{Ca}^{2+}\right]_{\mathrm{i}}$ were examined under a $40 \times$ oil immersion objective during exposure to alternating 340- and 380-nm light beams, and the intensity of light emission at $520 \mathrm{~nm}$ was measured. The ratio of light intensities, $F_{340} / F_{380}$, which reflects changes in $\left[\mathrm{Ca}^{2+}\right]_{\mathrm{i}}$, was simultaneously followed in several single cells. EGFP was used as a marker for selection of cells expressing P2XR. Cells expressing EGFP were optically detected by an emission signal at $520 \mathrm{~nm}$ when excited by $488-\mathrm{nm}$ ultraviolet light. Experiments were done in cells with comparable GFP fluorescence intensities (about 60 arbitrary units) and no repetitive stimulation was done to avoid the possible impact of desensitization on the amplitude and pattern of $\left[\mathrm{Ca}^{2+}\right]_{i}$ signals.

\section{Results}

Release of ATP and PRL

The release of ATP was studied in hypothalamic and pituitary cells in static culture and in perifusion. In static cultures of GT1-7, $\alpha \mathrm{T} 3-1$ and $\mathrm{GH}_{3}$ cells, the replacement of medium was used as stimulus for ATP release. In general, the release of ATP was dependent on cell number and duration of incubation. As shown in Figure 1a, within $5 \mathrm{~min}$ after the addition of ATP-free fresh medium to $1 \times$ $10^{5}$ GT1-7 cells there was an accumulation of ATP to about $80 \mathrm{nM}$ ATP, whereas in medium from dishes with $5 \times 10^{5}$ cells the measured ATP concentration was about $160 \mathrm{nM}$. In medium from dishes without cells there was practically no measurable ATP. Further incubation of cells was followed by a progressive decrease in ATP concentrations in medium. The release of ATP was not unique for GT1-7 cells, but was also observed in pituitary cells. Figure $1 \mathrm{~b}$ compares the time course of ATP release in GT1-7, $\mathrm{GH}_{3}$ and $\alpha \mathrm{T} 3-1$ cells; in all cultures a rapid ATP release during the first $5 \mathrm{~min}$ of incubation was followed by a progressive decrease in ATP concentrations as their incubation times were extended (Figure 1b). 
a

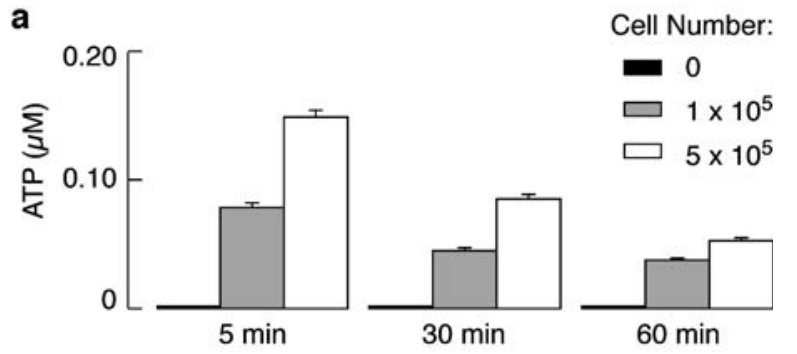

b

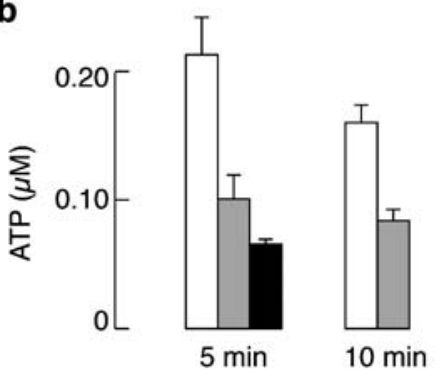

c

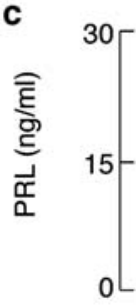

Cell Number:

$60 \mathrm{~min}$

replacement of medium reflects the time needed to reach a balance between ATP release and its degradation by ectonucleotidases.

In additional experiments aimed to further exclude the possible impact of lysis of cells on ATP release, GT1-7, $\alpha \mathrm{T} 3-1$ and $\mathrm{GH}_{3}$ cells were attached on beads and perifused for $150 \mathrm{~min}$ with ATP-free buffer at flow rate of $0.8 \mathrm{ml} /$ min, prior to sample collection for ATP measurements. This time was sufficient to stabilize basal hormone secretion, as illustrated in Figure 2a for PRL release by perifused $\mathrm{GH}_{3}$ cells. In the same samples there were measurable levels of ATP, indicating that perifused $\mathrm{GH}_{3}$ cells also release this nucleotide (Figure 2b). Consistent with the findings in cells in static cultures, ATP was also released by perifused GT1-7 and $\alpha$ T3 cells (Figure 2b). Again, there was no strict correlation between ATP and PRL secretory profiles in perifused $\mathrm{GH}_{3}$ cells.

\section{Expression and activity of ecto-nucleotidase (eNTPDase) 1-3}

To clarify whether the plasma membrane-associated ectonucleotidases are expressed in these cells, RT-PCR analysis

a

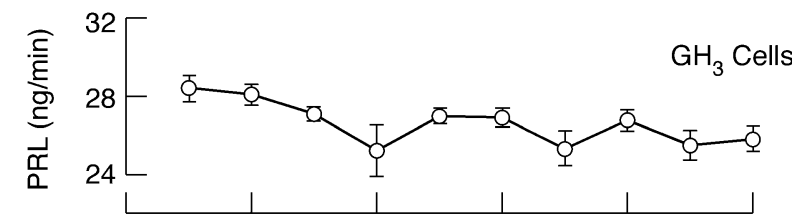

b

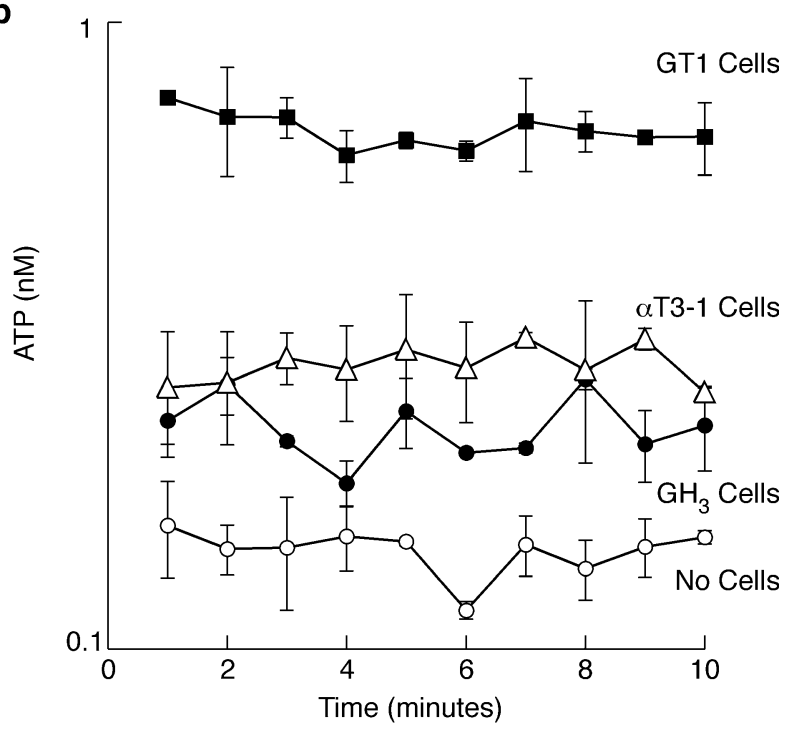

Figure 2. Constitutive PRL (a) and ATP (b) release by perifused hypothalamic and pituitary cell lines. Prior to experiments, cells $(5 \times$ $10^{6}$ ) attached on beads were transferred into $0.5-\mathrm{ml}$ chamber and perifused with ATP-free Krebs-Ringer medium for $2.5 \mathrm{~h}$ to establish a stable baseline. During experiments, samples were collected every minute and immediately tested for ATP and PRL concentrations. Chambers loaded with beads without cells were used as controls. In this and following figures with perifused pituitary cells, data points are means \pm SEM from three independent experiments. 
a

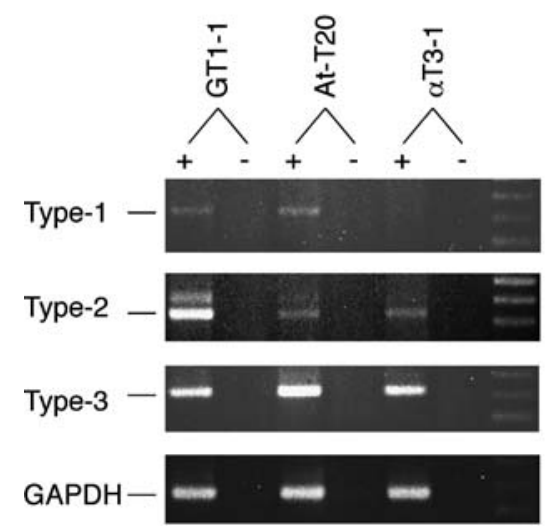

b

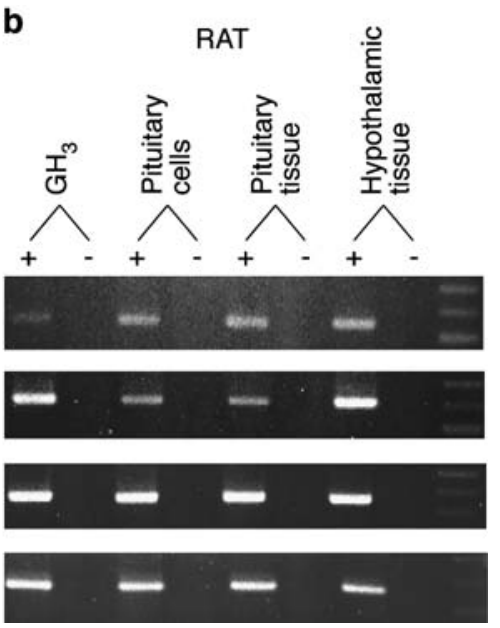

Figure 3. Expression of eNTPDase 1-3 transcripts in hypothalamic and pituitary tissues and cells. For negative controls, PCR was conducted performing first-strand cDNA synthesis without RT (-). In both panels, DNA markers are shown in the last right lanes. (a) Mouse cell lines. (b) Rat cells and tissues. GAPDH primers were used as internal control to monitor the quality of RNA preparation. For details, see Materials and methods.

was performed using specific primers for three known plasma membrane-associated eNTPDase subtypes. The mRNA transcripts of eNTPDase were expressed in mouse and rat hypothalamic and pituitary cells, as well as in mouse AtT20 pituitary cells and GT1 hypothalamic cells (Figure 3a). All three transcripts were also expressed in rat hypothalamic and pituitary tissues, dispersed pituitary cells cultured for $24 \mathrm{~h}$, and $\mathrm{GH}_{3}$ cells (Figure 3b). However, we were unable to observe the presence of specific transcripts for eNTPDase-1 in mouse $\alpha \mathrm{T} 3-1$ immortalized gonadotrophs, whereas the transcripts for the other two isoforms were present in this cell type (Figure 3a).

In order to estimate the capacity of endogenous ectonucleotidase to degrade ATP, hypothalamic and pituitary cells were transiently perifused with $10 \mu \mathrm{M}$ ATP at flow rate of $0.8 \mathrm{ml} / \mathrm{min}$ and the nucleotide concentration was measured in medium prior, during and after ATP application. In media from columns without cells, the measured levels of ATP were between 8.5 and $10 \mu \mathrm{M}$, whereas there was a substantial decrease of ATP concentrations in media from columns containing cells. Figure 4 illustrates that in all cases steady levels of ATP were reached within 2-3 min of nucleotide addition. The level of ATP degradation was dependent on cell type in order: Pituitary cells $>\mathrm{GH}_{3}>$ GT1-7 $>\alpha$ T3-1. These results indicate that eNTPDases expressed in hypothalamic and pituitary cells are functional enzymes and provide an effective mechanism for the control of the extracellular messenger functions of endogenously released ATP.

\section{Blockade of ecto-nucleotidase activity}

We initially used $\alpha \beta$-meATP, a slow degradable agonist [3], to inhibit the endogenous ecto-nucleotidase activity in hypothalamic and pituitary cells. Unfortunately, this compound interfered with ATP measurements in our assay. Therefore, we used ARL67156, a relatively specific blocker of these enzymes [28]. Pituitary cells were perifused with the blocker in order to characterize changes in the levels of both endogenously released and exogenously added ATP. Inhibition of pituitary ecto-nucleotidases by $50 \mu \mathrm{M}$ ARL67156 was sufficient to detect an increase in endogenous ATP release. Figure 5a illustrates a progressive increase in ATP concentrations in medium during ARL67156

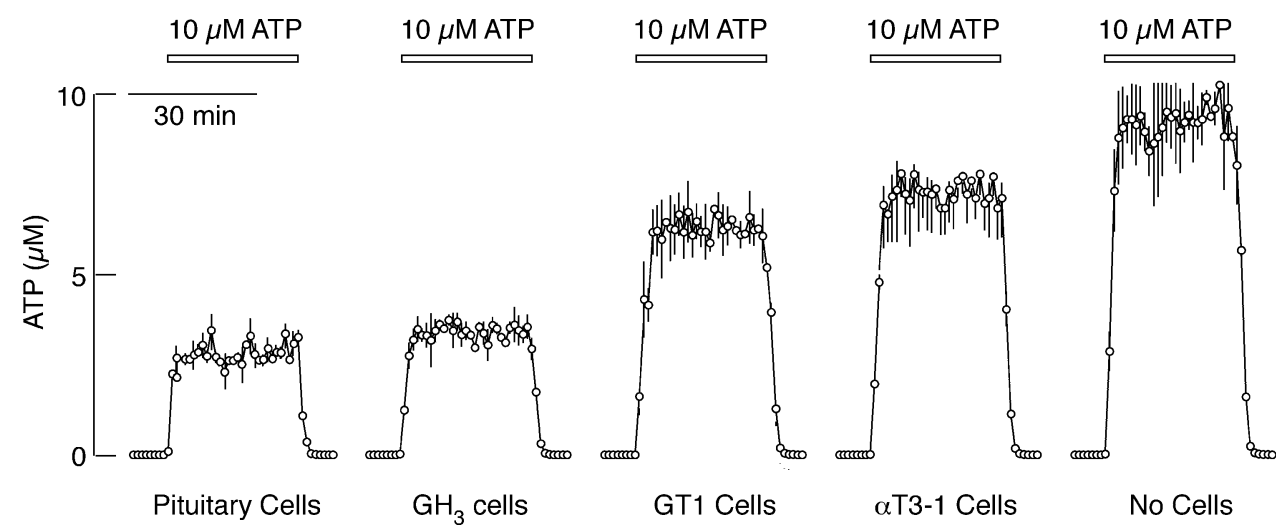

Figure 4. Cell-type specificity of extracellular ATP metabolism. Chamber without or with cells $\left(5 \times 10^{6}\right.$ per column $)$ were perifused with Krebs-Ringer buffer at flow rate of $0.8 \mathrm{ml} / \mathrm{min}$. Samples were collected every minute and immediately tested for ATP concentration. Horizontal bars above traces indicate the duration of ATP application. 
a

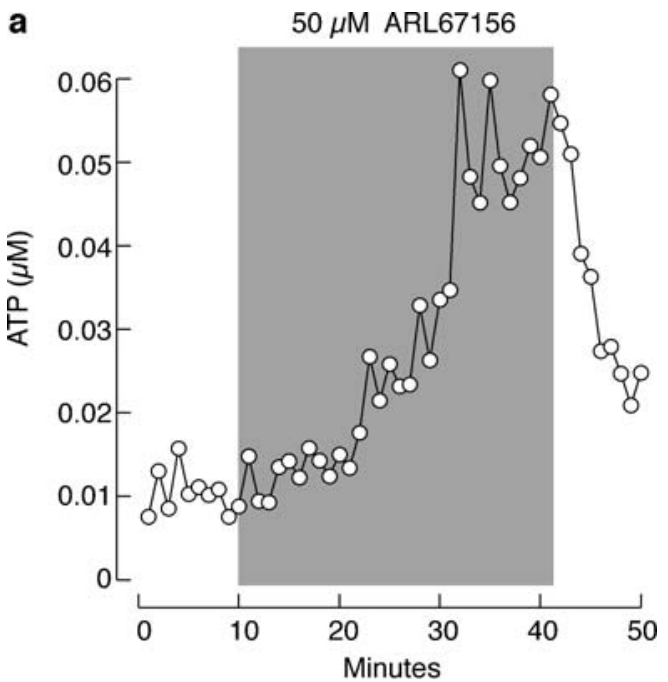

b

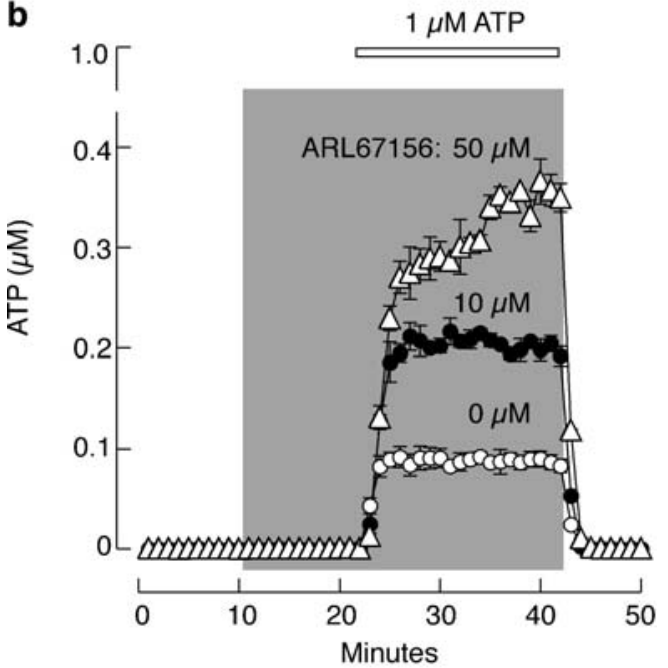

C

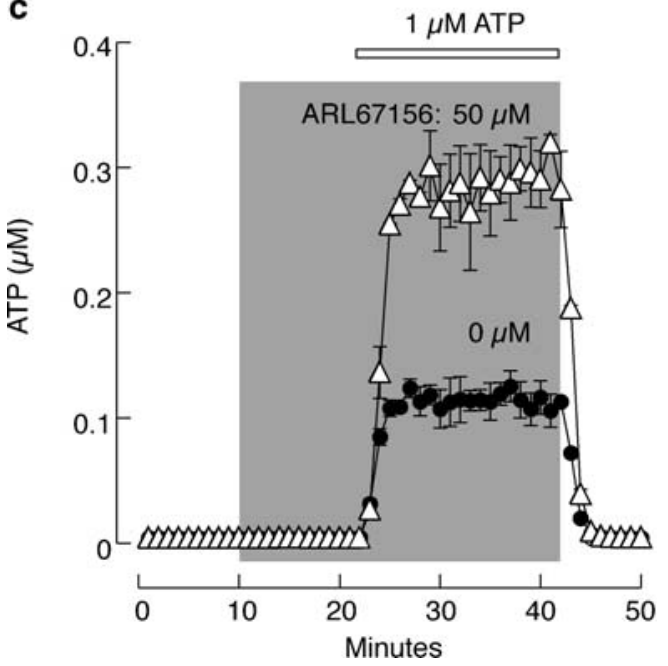

Figure 5. Effects of ARL67156 on ATP release and metabolism in perifused pituitary and $\mathrm{GH}_{3}$ cells. (a) Increase in endogenous ATP levels in pituitary cells perifused with ARL67156. (b) Concentration-dependent effects of ARL67156 on degradation of exogenously added ATP in pituitary cells. (c) Effects of ARL67156 on ATP metabolism in perifused $\mathrm{GH}_{3}$ cells. Gray areas indicate the duration of ARL67156 treatment and horizontal bars indicate the duration of ATP application. application to cells perifused at flow rate of $0.8 \mathrm{ml} / \mathrm{min}$, as well as a decrease in medium ATP content after removal of this blocker. These results confirmed not only that the endogenously released ATP was not due to cell lysis, but also that measured ATP concentrations reflect the balance between de novo released and metabolized nucleotide.

Degradation of extracellularly added ATP by perifused pituitary cells was also inhibited in a concentrationdependent manner by ARL67156. However, the majority of ATP was still degraded in the presence of $50 \mu \mathrm{M}$ ARL67156 (Figure 5b). The effect of this compound on degradation of exogenously added ATP was not only observed in normal pituitary cells but also in perifused $\mathrm{GH}_{3}$ cells. In experimental conditions shown in Figure 5c, about $90 \%$ of added ATP $(1 \mu \mathrm{M})$ was degraded in control $\mathrm{GH}_{3}$ cells and about $70 \%$ in $50 \mu \mathrm{M}$ ARL67156-treated cells. Thus, a rapid and dramatic decrease in exogenously added ATP concentration in perifused cells also reflects a high activity of endogenous ecto-nucleotidase.

\section{Facilitation of ATP degradation}

To enhance degradation of ATP, two experimental approaches were used: Overexpression of mouse eNTPDase2 and the addition of apyrase, a plant soluble ectonucleotidase. eNTPDase-2 was overexpressed in two cell

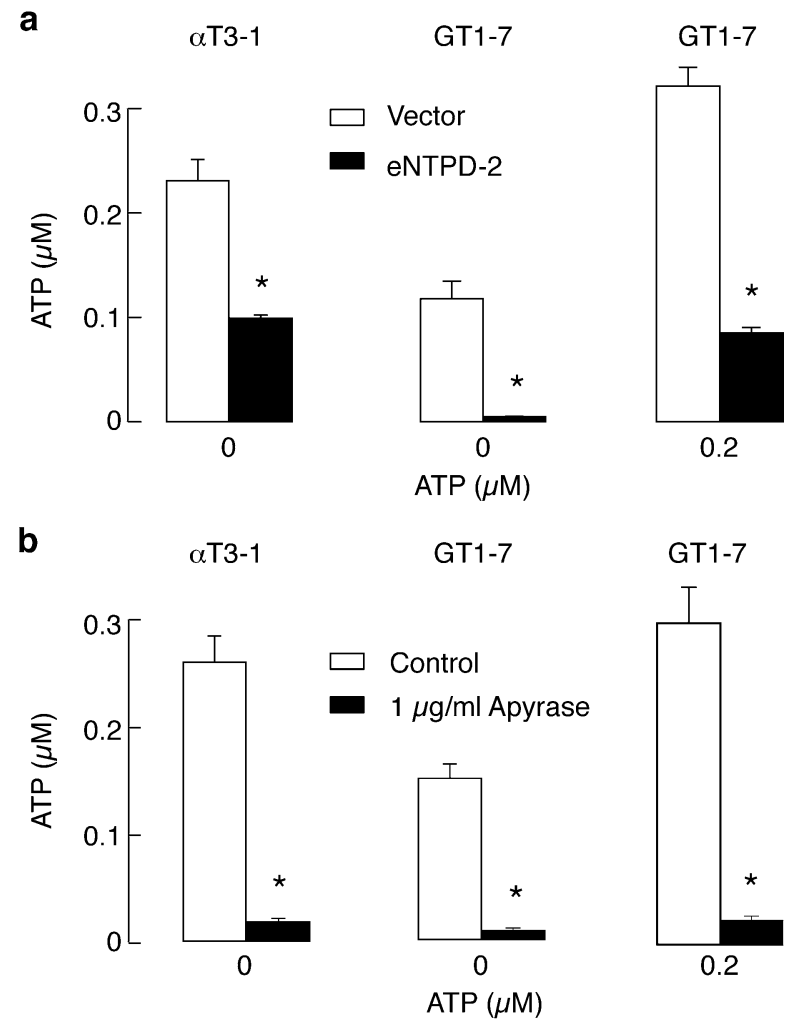

Figure 6. Facilitation of ATP metabolism by over-expression of mouse ecto-ATPase eNTPDase-2 (a) and addition of $1 \mu \mathrm{g} / \mathrm{ml}$ apyrase (b) in $\alpha \mathrm{T} 3-1$ and GT1-7 cells. Culture medium was washed and replaced with ATP-free or ATP-containing Krebs-Ringer buffer and cells were incubated for $5 \mathrm{~min}$. Numbers below the bars indicate amounts of ATP added to the buffer. Asterisks indicate significant differences between pairs $(P<0.01)$. For details see Materials and methods. 
lines derived from mouse, $\alpha$ T3-1 and GT1-7 cells. Twentyfour hours after transfection, cells were washed and samples for ATP measurements were collected $5 \mathrm{~min}$ after replacing the medium. As shown in Figure 6a, left panel, ATP was released in both vector controls and eNTPDase-2-expressing $\alpha$ T3-1 cells, but the level of ATP measured in cells overexpressing the enzyme was significantly lower. In GT1-7 cells over-expressing mouse eNTPDase type-2, 5-min incubation was sufficient to metabolize the majority of de novo ATP release (Figure $6 \mathrm{a}$, central panel). The exogenously added ATP $(200 \mathrm{nM})$ was also rapidly degraded (Figure 6a, right panel). The addition of apyrase practically masked the endogenously released ATP from both $\alpha \mathrm{T} 3-1$ and GT1-7 cells (Figure 6b) and degraded the majority of extracellularly added ATP within 5 min of incubation (Figure 6b, right panel).

\section{Desensitization of P2XRs by endogenously released ATP}

To examine the biological activity of endogenously released ATP, we expressed recombinant P2XRs in GT1-7 cells, which do not bear endogenous purinergic receptors [19]. We purposely selected $P 2 X_{2 a} R, P 2 X_{2 b} R, P 2 X_{3} R$ and two chimeras having the ectodomain of $\mathrm{P} 2 \mathrm{X}_{3} \mathrm{R}$ in the backbone of $\mathrm{P} 2 \mathrm{X}_{2} \mathrm{Rs}\left(\mathrm{P} 2 \mathrm{X}_{2 \mathrm{a}} / \mathrm{V}^{60}-\mathrm{F}^{301} \mathrm{X}_{3}\right.$ and $\mathrm{P} 2 \mathrm{X}_{2 \mathrm{~b}} / \mathrm{V}^{60}$ $\mathrm{F}^{301} \mathrm{X}_{3}$ ), because these receptors differ in their $\mathrm{EC}_{50} \mathrm{~s}$ for ATP: About $50 \mathrm{nM}$ for $\mathrm{P} 2 \mathrm{X}_{3} \mathrm{R}$ and $\mathrm{P} 2 \mathrm{X}_{2} / \mathrm{X}_{3} \mathrm{R}$ chimera, which is in the range of ATP concentrations in medium from cells in resting conditions (Figure 1) and about $3 \mu \mathrm{M}$ for $\mathrm{P} 2 \mathrm{X}_{2 \mathrm{a}} \mathrm{R}$ and $\mathrm{P} 2 \mathrm{X}_{2 \mathrm{~b}} \mathrm{R}$ [29]. After replacement of media, cells were either incubated for 15 and $60 \mathrm{~min}$ in the absence of apyrase, or incubated for $1-4 \mathrm{~h}$ in the presence of apyrase. After the indicated incubation periods, control and apyrase-treated cells were stimulated with $10 \mu \mathrm{M}$ ATP. Cells treated with apyrase were also stimulated with conditioned media collected from cultures of GT1-7 neurons incubated for $5 \mathrm{~min}$. Single cell calcium measurements were used to detect the activity of receptors upon ATP stimulation.

After $60 \mathrm{~min}$ of incubation in medium without apyrase, none of the $\mathrm{P} 2 \mathrm{X}_{3} \mathrm{R}$-expressing cells (57 out of 57) showed elevation in $\left[\mathrm{Ca}^{2+}\right]_{i}$ in response to ATP stimulation (Figure 7a, left panel). Practically, 15 min of incubation in medium without apyrase was sufficient to abolish responsiveness of the majority of $\mathrm{P}_{2} \mathrm{X}_{3} \mathrm{R}$ expressing cells and only in a small fraction of cells a small amplitude $\left[\mathrm{Ca}^{2+}\right]_{\mathrm{i}}$ signal was observed (Figure $7 \mathrm{a}$, central panel). In cultures incubated for $60 \mathrm{~min}$ with apyrase-containing medium, the responsiveness to ATP was established in all (49 out of 49) cells, clearly indicating that the endogenously released ATP was sufficient to activate and desensitize these receptors (Figure $7 \mathrm{a}$, right panel). Consistent with this conclusion, in apyrase-treated GT1-7 neurons expressing $\mathrm{P} 2 \mathrm{X}_{3} \mathrm{R}$ the addition of conditioned medium from resting cells triggered response in some (23 out of 41 ) cells (data not shown).

Under resting conditions, 60-min incubation also led to the loss of responsiveness of all $\mathrm{P} 2 \mathrm{X}_{2 \mathrm{a}} / \mathrm{V}^{60}-\mathrm{F}^{301} \mathrm{X}_{3}$ and

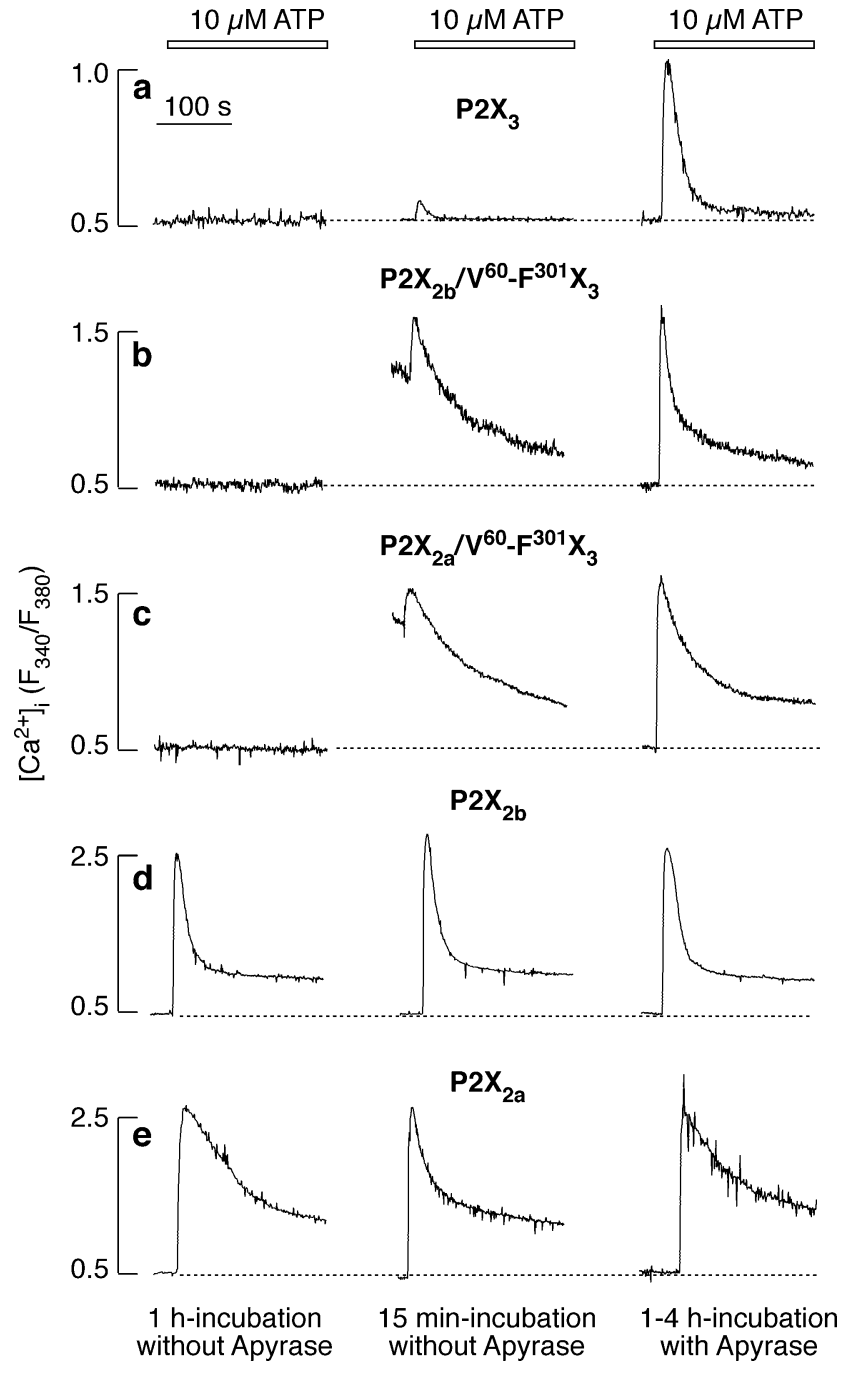

Figure 7. Desensitization of recombinant rat P2XRs expressed in GT1-7 cells by endogenous ATP. Left column: The lack of effects of exogenously added ATP on activation of $\mathrm{P} 2 \mathrm{X}_{3} \mathrm{R}$ (a) and chimeric receptors (b and c), but not $\mathrm{P} 2 \mathrm{X}_{2} \mathrm{Rs}$ ( $\mathrm{d}$ and e), in cells cultured in medium without apyrase, a soluble ecto-ATPase, for $60 \mathrm{~min}$. Central column: Patterns of ATPinduced $\left[\mathrm{Ca}^{2+}\right]_{\mathrm{i}}$ signaling by parental receptors and their chimeras in cells incubated in medium without apyrase for $15 \mathrm{~min}$. Right column: Patterns of ATP-induced $\left[\mathrm{Ca}^{2+}\right]_{\mathrm{i}}$ signaling by parental and chimeric receptors in cells incubated in medium containing apyrase. In dishes with parental receptors the enzyme was present for $1 \mathrm{~h}$, whereas in those with cells expressing chimeras apyrase was present at least $4 \mathrm{~h}$. Traces shown are mean values from at least 10 EGFP-positive cells in one from three to five dishes. For details on expression of P2XRs, see Materials and methods.

$\mathrm{P} 2 \mathrm{X}_{2 \mathrm{~b}} / \mathrm{V}^{60}-\mathrm{F}^{301} \mathrm{X}_{3}$-expressing cells (85 out of 85 , combined together for both receptors; Figures $7 \mathrm{~b}$ and $\mathrm{c}$, left panels). In a substantial fraction of cells incubated for 15 min (24 out of 73 cells) basal $\left[\mathrm{Ca}^{2+}\right]_{\text {i }}$ was elevated and the addition of ATP led to further increase in $\left[\mathrm{Ca}^{2+}\right]_{\mathrm{i}}$, followed by a progressive decrease below the initial values (Figures $7 \mathrm{~b}$ and $\mathrm{c}$, central panels). In cells bathed in apyrase $(1$ microgram $/ \mathrm{ml})$-containing medium for $4 \mathrm{~h}$, ATP induced typical a pattern of calcium signals, determined by the rates of activation and desensitization of receptors (Figures $7 \mathrm{~b}$ and c, right panels). In apyrase-pretreated cells, the addition of conditioned medium collected from resting cells elevated $\left[\mathrm{Ca}^{2+}\right]_{i}$ in 21 out of 46 cells, confirming that 
the released ATP from resting cells is sufficient to reach the threshold level for activation of these receptors (data not shown).

In contrast to $\mathrm{P} 2 \mathrm{X}_{3} \mathrm{R}$ and chimeric receptors, all $\mathrm{P} 2 \mathrm{X}_{2 \mathrm{a}} \mathrm{R}$ and $\mathrm{P} 2 \mathrm{X}_{2 \mathrm{~b}} \mathrm{R}$-expressing cells responded to ATP stimulation independently of the duration of resting period and presence/absence of apyrase (Figures $7 d$ and e), indicating that in these experimental conditions the level of endogenously released ATP is below the threshold dose required for activation and desensitization of these two receptors. In accordance with this, conditioned media from resting cells triggered $\left[\mathrm{Ca}^{2+}\right]_{\mathrm{i}}$ signals in none of the $\mathrm{P} 2 \mathrm{X}_{2 \mathrm{a}} \mathrm{R}$ and $\mathrm{P} 2 \mathrm{X}_{2 \mathrm{~b}} \mathrm{R}$-expressing cells (35 out of 35 ; data not shown). All together, these results indicate that endogenously released ATP is biologically active and that in vitro released ATP levels are sufficient to activate and desensitize high affinity receptors.

\section{Discussion}

The presence of phospholipase C-coupled P2YRs was initially observed in a mixed population of sheep pituitary cells $[12,13]$. Subsequent studies showed that rat pituitary cells also express P2YRs; their activation by ATP is associated with an elevation in $\left[\mathrm{Ca}^{2+}\right]_{i}$ due to release of calcium from intracellular stores $[10,11,30]$. Molecular cloning and functional characterization of rat P2YRs in the pituitary revealed the expression of $\mathrm{P} 2 \mathrm{Y}_{2} \mathrm{R}$ with the pharmacological profile resembling the one observed in sheep pituitary cells [15]. Additional studies have suggested the presence of P2XRs in normal and immortalized pituitary cells $[8,9,14]$. Initially, the mRNAs for $P 2 X_{2 a} R$ and its spliced form, $\mathrm{P} 2 \mathrm{X}_{2 \mathrm{~b}} \mathrm{R}$, were found in pituitary cells and functional receptors were identified in gonadotrophs and somatotrophs $[18,19,31,32]$. This was followed by discovery of transcripts for $\mathrm{P} 2 \mathrm{X}_{3} \mathrm{R}, \mathrm{P} 2 \mathrm{X}_{4} \mathrm{R}$, and $\mathrm{P} 2 \mathrm{X}_{7} \mathrm{R}$ in pituitary cells [17], and the finding that lactotrophs express $\mathrm{P} 2 \mathrm{X}_{4} \mathrm{R}$, which plays a major role in control of calciuminflux-dependent PRL release [16]. Transcripts for $\mathrm{P} 2 \mathrm{Y}_{1} \mathrm{R}$, $\mathrm{P} 2 \mathrm{Y}_{4} \mathrm{R}$, and $\mathrm{P} 2 \mathrm{Y}_{6} \mathrm{R}$ have also been detected in anterior pituitary cells and functional $\mathrm{P} 2 \mathrm{Y}_{1} \mathrm{R}$ were identified in lactotrophs [16]. Adenosine also operates as an extracellular messenger in anterior pituitary cells by activating $A_{1}$, $A_{2 A}$ and $A_{2 B}$ receptors [5]. Such a complex expression pattern of P1Rs and P2Rs is consistent with the hypothesis that purinergic receptors play important roles in control of anterior pituitary functions.

The physiological sources of extracellular nucleotides required for activation of these receptors in pituitary cells remains largely uncharacterized. Here we show that ATP is released by normal and immortalized pituitary cells, as well as by GT1-7 cells, at resting conditions. Three lines of evidence argues against the hypothesis that lysis of cells underlies ATP release. A rapid increase in ATP release in $\mathrm{GH}_{3}$ cells in static cultures after medium replacement was not accompanied with rapid PRL release. ATP was also released by pituitary cells perifused for $2.5 \mathrm{~h}$ at flow rate of $0.8 \mathrm{ml} / \mathrm{min}$. Finally, there is a gradual and transient increase in the rate of ATP release in the presence of ARL67156. In general, neurons, neuroendocrine cells and platelets release ATP by calciumcontrolled exocytosis of nucleotides stored within synaptic vesicles or dense core granules [33]. Since anterior pituitary cells secrete hormones by exocytotic pathway, it is reasonable to postulate that ATP is also released through the same pathway. However, in this study we were unable to observe a correlation between ATP and PRL release in resting $\mathrm{GH}_{3}$ cells. It is well established that purinergic receptors are also expressed in cell types that do not secrete by exocytosis [2]. This suggests that ATP could also be released by another mechanism, but the nature of this pathway is not known at the present time [34]. Both secretory and non-secretory ATP release pathways are probably operative in human astrocytes [35], whereas further studies are needed to clarify which mechanism is responsible for ATP release in pituitary cells.

Although the action of ATP as an autocrine/paracrine factor is critically dependent on its rapid metabolism by ecto-nucleotidases, the expression and role of these enzymes in control of nucleotide-dependent signaling in pituitary cells was not previously addressed. Here we provide evidence that these enzymes are expressed and operative in hypothalamic and pituitary cells. First, we show that transcripts for three plasma membrane-located eNTPDases are expressed in hypothalamic and pituitary tissues, cultured pituitary cells and immortalized lacto-somatotrophs, corticotrophs, gonadotrophs and GnRH-secreting cells. We also show that these enzymes are capable of degrading both endogenously released and exogenously added ATP. Depending on the cell type, $5 \times 10^{6}$ cells perifused at flow rate of $0.8 \mathrm{ml} / \mathrm{min}$ were able to degrade $27 \%-70 \%$ of extracellularly added ATP. Finally, we show the impact of inhibition of these enzymes on ATP degradation. Thus, the ATP concentration measured in our experimental conditions reflects the equilibrium between the rate of ATP release and the rate of ATP hydrolysis by endogenously expressed ecto-nucleotidases.

In general, there are three possible ways to attenuate the endogenous ecto-nucleotidase activity in a particular cell type: Removal of calcium, addition of slow-metabolizing agonists and application of ecto-nucleotidase-specific inhibitors. The activity of these enzymes depends on extracellular calcium concentration [3]. However, calcium is also required for activation of exocytosis, which in lactotrophs and somatotrophs occurs in the absence of agonist stimulation and is driven by spontaneous voltagegated calcium influx [36]. Thus, removal of calcium also affects both hormone secretion and the associated ATP cosecretion. The ecto-nucleotidases are also blockable by $\alpha \beta-$ methylene ATP [3], but this slow metabolizing agonist interferes with ATP measurements in our assay, which is not the case for ARL67156, a specific inhibitor for some ecto-nucleotidases. This compound significantly and reversibly inhibited ATP degradation in normal and immortalized pituitary cells. Inhibition of metabolism of ATP by ARL67156 clearly indicates that the released ATP is not due to cell lysis or loss of plasma membrane integrity, but reflects an active process. However, the potency of 
ARL67156 to inhibit pituitary ecto-nucleotidase is not high enough, which limits the utility of this blocker for further investigations on the rate and mechanism of ATP release by pituitary cells.

One may speculate that the endogenously released ATP by hypothalamic and pituitary cells is not biologically active or it is below the threshold required for activation of P2Rs. To test this hypothesis, we expressed $\mathrm{P} 2 \mathrm{X}_{2} \mathrm{R}$ and $\mathrm{P} 2 \mathrm{X}_{3} \mathrm{R}$ in GT1-7 cells. At the density of $1 \times$ $10^{5}$ cells per $35 \mathrm{~mm}$ coverslip, our results indicate that the endogenously released ATP was sufficient to desensitize $\mathrm{P} 2 \mathrm{X}_{3} \mathrm{R}$ and $\mathrm{P} 2 \mathrm{X}_{2} / \mathrm{X}_{3}$ chimeras, but not $\mathrm{P} 2 \mathrm{X}_{2} \mathrm{R}$. This was further supported by the finding that the ATP concentrations in conditioned culture medium are comparable to the $\mathrm{EC}_{50}$ values required for activation of $\mathrm{P} 2 \mathrm{X}_{3} \mathrm{R}$. Thus, the endogenously released ATP is biologically active and is able to stimulate at least a fraction of $\mathrm{P} 2 \mathrm{R}$ subtypes expressed in these cells. Certainly, these in vitro conditions should not fairly reflect the in vivo situation, where tissue ATP concentration reflects a balance between rates of release, hydrolysis and dilution into intercellular compartment.

Limited information exists about the roles of P2XR in hypothalamic and pituitary cells and the integration of P1Rs in signaling through ecto-nucleotidase-dependent conversion of ATP to adenosine. Stimulation of LH and PRL release by addition of ATP has been previously shown $[7,14,16]$. We may also speculate that the actions of ATP as an autocrine and paracrine factor in pituitary cells, which express numerous P2YRs and P2XRs, provide a potential mechanism for a progressive amplification of ATP secretory response and a dose-dependent activation of specific receptors. Although gap junction channels contribute to synchronized calcium signaling among pituitary cells [37], it is also reasonable to speculate that extracellular ATP plays a role in intercellular propagation of calcium waves between secretory and non-secretory anterior pituitary cell types. Finally, the finding that GT1-7 neurons release ATP but do not express P2Rs may indicate that in vivo GnRH neurons influence other P2R-expressing neurons through ATP-mediated synaptic transmission rather than by GnRH.

In summary, we show that ATP is released by hypothalamic and pituitary cells and is metabolized by ecto-nucleotidases. The release of ATP is not due to lysis of cells but reflects an active process. Moreover, endogenously released ATP is biologically active and its in vitro levels are sufficient to stimulate and desensitize P2XRs, according to their ligand affinity. The signaling functions of ATP are inhibited by ARL67156-sensitive ecto-nucleotidases. These results are consistent with the hypothesis that in pituitary cells P2Rs and ecto-nucleotidases compete for a limited pool of endogenously released ATP. The ectonucleotide cascade not only terminates the extracellular messenger functions of ATP but also provides a pathway for the generation of ADP and adenosine, which in pituitary cells may activate some P2YRs and P1Rs, respectively. Finally, these enzymes may build up a mechanism for the control of ligand-dependent desensiti- zation of purinergic receptors within the pituitary, which may be relevant to the homeostasis of the gland.

\section{References}

1. Zimmermann H. Extracellular metabolism of ATP and other nucleotides. Naunyn-Schmiedeberg's Arch Pharmacol 2000; 362: 299-309.

2. Ralevic V, Burnstock G. Receptors for purines and pyrimidines. Pharmacol Rev 1998; 50: 413-92.

3. Pearson JD. Ectonucleotidases: Measurement of activities and use of inhibitors. Methods Pharmacol 1985; 6: 83-107.

4. Rees DA, Scanlon MF, Ham J. Novel insights into how purines regulate pituitary cell function. Clin Sci 2003; 104: 467-81.

5. Rees DA, Scanlon MF, Ham J. Adenosine signalling pathway in the pituitary gland: One ligand, multiple receptors. J Endocrinol 2003; 177: 357-64.

6. Kumari M, Buckingham JC, Poyser RH, Cover PO. Roles for adenosine A1- and A2-receptors in the control of thyrotrophin and prolactin release from the anterior pituitary gland. Regul Pept 1999; 79: 41-6.

7. Nunez L, Villalobos C, Frawley LS. Extracellular ATP as an autocrine/paracrine regulator of prolactin release. Am J Physiol 1997; 272: E1117-23.

8. Villalobos C, Alonso-Torre SR, Nunez L, Garcia-Sancho J. Functional ATP receptors in rat anterior pituitary cells. Am J Physiol 1997; 273: C1963-71.

9. Chung HS, Park KS, Cha SK et al. ATP-induced $\left[\mathrm{Ca}^{2+}\right]_{\mathrm{i}}$ changes and depolarization in GH3 cells. Br J Pharmacol 2000; 130: 1843-52.

10. Chen Z-P, Levy A, McArdle CA, Lightman SL. Pituitary ATP receptors: Characterization and functional localization to gonadotropes. Endocrinology 1994; 135: 1280-4.

11. Chen Z-P, Kratzmeier M, Poch A et al. Effects of extracellular nucleotides in the pituitary: Adenosine triphosphate receptor-mediated intracellular responses in gonadotrope-derived $\alpha \mathrm{T} 3-1$ cells. Endocrinology 1996; 137: 248-56.

12. Van Der Merwe PA, Wakefield IK, Fine J et al. Extracellular adenosine triphosphate activates phospholipase $\mathrm{C}$ and mobilizes intracellular calcium in primary cultures of sheep anterior pituitary cells. FEBS Lett 1989; 243: 333-6.

13. Davidson JS, Wakefield IK, Sohnius U et al. A novel extracellular nucleotide receptor coupled to phosphoinositidase-C in pituitary cells. Endocrinology 1990; 126: 80-7.

14. Tomic M, Jobin RM, Vergara LA, Stojilkovic SS. Expression of purinergic receptor channels in their role in calcium signaling and hormone release in pituitary gonadotrophs. J Biol Chem 1996; 271: 21200-8.

15. Chen Z-P, Krull N, Xu L et al. Molecular cloning and functional characterization of a rat pituitary $G$ protein-coupled adenosine triphosphate (ATP) receptor. Endocrinology 1996; 137: 1833-40.

16. He M-L, Gonzalez-Iglesias AE, Stojilkovic SS. Role of nucleotide $\mathrm{P} 2$ receptors in calcium signaling and prolactin release in pituitary lactotrophs. J Biol Chem 2003; 278: 46270-7.

17. Koshimizu T, Tomic M, Wong AOL et al. Characterization of purinergic receptors and receptor-channels expressed in anterior pituitary cells. Endocrinology 2000; 141: 4091-9.

18. Lynch KJ, Touma E, Niforatos W et al. Molecular and functional characetrization of human $\mathrm{P}_{2} \mathrm{X}_{2}$ receptors. Mol Pharmacol 1999; 56: $1171-81$.

19. Koshimizu T, Tomic M, Van Goor F, Stojilkovic SS. Functional role of alternative splicing in pituitary $\mathrm{P} 2 \mathrm{X}_{2}$ receptor-channel activation and desensitization. Mol Endocrinol 1998; 12: 901-13.

20. Troadec JD, Thirion S, Petturiti D et al. ATP acting on P2Y receptors triggers calcium mobilization in primary cultures of rat neurohypophysial astrocytes. Pflugers Arch 1999; 437: 745-53.

21. Kapoor JR, Sladek CD. Purinergic and adrenergic agonists synergize in stimulating vasopressin and oxytocin release. J Neurosci 2000; 20: 8868-75.

22. Uchiyama M, Nakajima Y, Sakuma Y, Kato M. Purinergic regulation 
of intracellular $\mathrm{Ca}^{2+}$ concentration of rat pituitary folliculo-stellate cells in primary culture. J Neuroendocrinol 2001; 13: 378-85.

23. Loesch A, Miah S, Burnstock G. Ultrastructural localization of ATPgated P2X2 receptor immunoreactivity in the rat hypothalamoneurohypophysial system. J Neurocytol 1999; 28: 495-504.

24. Chen Z-P, Kratzmeier M, Levy A et al. Evidence for a role of pituitary ATP receptors in the regulation of pituitary function. Proc Natl Acad Sci USA 1995; 92: 5219-23.

25. Koshimizu T, Van Goor F, Tomic M et al. Characterization of calcium signaling by purinergic receptor-channels expressed in excitable cells. Mol Pharmacol 2000; 58: 936-45.

26. Koshimizu T, Koshimizu M, Stojilkovic SS. Contributions of the C-terminal domain to the control of P2X receptor desensitization. J Biol Chem 1999; 274: 37651-7.

27. Koshimizu T, Ueno S, Tanoue A et al. Hetromultimerization modulates P2X receptor functions through participating extracellular and C-terminal subdomains. J Biol Chem 2002; 277: 46891-9.

28. Sesti C, Koyama M, Broekman MJ et al. Ectonucleotidase in sympathetic nerve endings modulates ATP and norepinephrine exocytosis in myocardial ischema. J Pharmacol Exp Ther 2003; 306: 238-44.

29. He M-L, Koshimizu T, Tomic M, Stojilkovic SS. Purinergic P2X receptor desensitization depends on coupling between ectodomain and C-terminal domain. Mol Pharmacol 2002; 62: 1187-97.
30. Carew MA, Wu M-L, Law GJ et al. Extracellular ATP activates calcium entry and mobilization via $\mathrm{P}_{2 \mathrm{U}}$-purinoceptors in rat lactotrophs. Cell Calcium 1994; 16: 227-35.

31. Koshimizu T, Tomic M, Koshimizu M, Stojilkovic SS. Identification of amino acid residues contributing to desensitization of the $\mathrm{P} 2 \mathrm{X}_{2}$ receptor channel. J Biol Chem 1998; 273: 12853-7.

32. Brake AJ, Wagenbach MJ, Julius D. New structural motif for ligandgated ion channels defined by an ionotropic ATP receptor. Nature 1994; 371: 519-23.

33. Unsworth CDJRJ. ATP compartmentation in neuroendocrine secretory vesicles. Ann NY Acad Sci 1990; 603: 353-63.

34. Schwiebert EM. ABC transporter-facilitated ATP conductive transport. Am. J Physiol 1999; 276: C1-8.

35. Joseph SM, Buchjakjian MR, Dubyak GR. Colocalization of ATP release sites and ecto-ATPase activity at the extracellular surface of human astrocytes. J Biol Chem 2003; 278: 23331-42.

36. Van Goor F, Zivadinovic D, Matinez-Fuentes AJ, Stojilkovic SS. Dependence of pituitary hormone secretion on the pattern of spontaneous voltage-gated calcium influx: Cell-type specific action potential-secretion coupling. J Biol Chem 2001; 276: 33840-6.

37. Fauquier T, Guerineau NC, McKinney RA et al. Folliculostellate cell network: A route for long-distance communication in the anterior pituitary. Proc Natl Acad Sci USA 2001; 98: 8891-6. 